\title{
Proosten met champagne, heel m'n libi is nu duur
}

\section{Opzichtige consumptie in Nederlandse rap}

\author{
Robbert Goverts \& Robert Roks
}

\section{Inleiding}

Het refrein van het in 2017 verschenen nummer $4 x$ Duurder van de Nederlandse rapartiesten SBMG, Lil Kleine en DJ Stijco draait om de zin 'Vier keer duurder, de mijne is vier keer duurder'. Door de veelvuldige herhalingen gedurende het nummer verwordt de zin tot een mantra dat op verschillende manieren gespecificeerd wordt door de rappers, onder andere door aan te geven dat hun horloges, wagens en kleding vier keer duurder zijn dan die van anderen. In de in Parijs opgenomen videoclip - goed voor meer dan 37 miljoen streams op YouTube - wordt dit narratief gevisualiseerd in de vorm van meerdere auto's uit de hogere prijssegmenten en rappers die aan beide polsen ogenschijnlijk dure horloges dragen. Lil Kleine een van de meest bekende en populaire Nederlandse rappers - etaleert zijn opzichtige consumptiepatroon uiterst beeldend wanneer hij gehuld in dure designerkleding op het dak van een Range Rover zit en een stapel 500 eurobiljetten uitstrooit, terwijl hij rapt: 'Ik ben geen tovenaar, maar blijf 't uitgeven, shit net alsof ik tover.'

Zowel in het nummer als de clip zien we wat socioloog Thorstein Veblen aan het einde van de negentiende eeuw in zijn The Theory of the Leisure Class (1899/2017) omschreef als 'conspicuous consumption'. ${ }^{1}$ Deze opzichtige manier van consumeren was in de tijd van de analyse van Veblen vooral voorbehouden aan de hogere klassen die luxegoederen kochten met als doel hun status in de samenleving te markeren 'by means of showing pecuniary strength' (Veblen, 2017: 57). In de (cultureel) criminologische literatuur wordt 'conspicuous consumption' veelal in verband gebracht met subculturen van de straat (Nightingale, 1993; Densley, 2013; Hallsworth, 2013; Ilan, 2015). De commercialisering en de mondiale populariteit van de hiphop, met rapmuziek als meest in het oog springende element van deze (sub)cultuur, wordt gezien als een van de drijvende krachten achter deze 'inner-city conspicuous consumption' (Hayward, 2004: 181). Hierbij lijkt sprake van een complexe feedbackloop tussen verbeelding en verwoording van luxegoederen in de rapteksten en -video's en de straten van de stedelijke omgeving waar jongeren vanwege de overvloed aan zichtbare merken fungeren als 'walking megamalls' (Pattillo-McCoy, 1999: 146).

In de Verenigde Staten is de relatie tussen hiphop en 'conspicuous consumption' op verschillende manieren object van studie geweest, onder andere ten aanzien

1 Omwille van de leesbaarheid van dit artikel maken we afwisselend gebruik van de Engelse term 'conspicuous consumption' en de Nederlandse vertaling 'opzichtige consumptie'. 
van attitudes van Afro-Amerikanen naar materialisme (Podoshen, Andrzejewski \& Hunt, 2014), in relatie tot seksualiteit (Miller-Young, 2008) en met betrekking tot genderrollen (Hunter, 2011). In Nederland is er echter, voor zover ons bekend, geen wetenschappelijk onderzoek verricht naar opzichtige consumptie in rapmuziek. Sterker, ondanks dat het genre de afgelopen jaren is uitgegroeid tot de meest populaire muziekstroming onder jongeren (Duijsings \& Van Niekerk, 2018), is de academische aandacht voor het bestuderen van Nederlandse rapteksten beperkt te noemen (zie o.a. Wermuth, 2002; Roks, 2013; Bakker \& Van de Wetering, 2015; De Roest, 2017). De recente (negatieve) maatschappelijke aandacht voor rap, onder andere vanwege een aantal geweldsincidenten in Rotterdam en Amsterdam die een overlap lijken te vertonen met rapmuziek (zie o.a. Berkelder, 2019; Bahara, 2019), onderschrijft het belang van een wetenschappelijke interpretatie en duiding van Nederlandstalige rapteksten. Waar het publieke debat een veelal negatieve (onder)toon kent wanneer het over hiphop gaat (Vughts, 2020), is in het academische debat juist meer ruimte voor nuance (De Roest, 2017; Ilan, 2020), alsmede aandacht voor positieve invloeden van muziek op jongeren (Van Bohemen, Den Hertog \& Van Zoonen, 2017). Met onze analyse van Nederlandstalige rapmuziek trachten wij een bijdrage te leveren aan een genuanceerd(er) publiek debat rondom hiphop in Nederland.

In deze bijdrage belichten we opzichtige consumptie in Nederlandse rapmuziek aan de hand van een analyse van de teksten op recente releases van de negentien meest populaire Nederlandstalige rappers uit 2018. ${ }^{2}$ Middels deze analyse proberen we antwoord te geven op de volgende onderzoeksvraag: hoe krijgt opzichtige consumptie in Nederlandstalige rapmuziek vorm en hoe wordt hier door rappers in hun teksten betekenis aan gegeven? Hiermee trachten we allereerst in kaart te brengen in hoeverre en hoe opzichtige consumptie in Nederlandstalige rapmuziek vorm en inhoud krijgt. Daarnaast richten we ons op de processen van betekenisgeving in de teksten van de rappers. Hierbij kijken we in hoeverre de rappers iets zeggen over de manieren waarop zij inkomsten verwerven en hun consumptiepatronen financieren, maar ook in hoeverre de rappers het hebben over de onderliggende motivaties en beweegredenen voor hun (opzichtige) consumptie.

Dit artikel is als volgt opgebouwd. We beginnen met een theoretische uiteenzetting van het begrip 'conspicuous consumption', zowel in de oorspronkelijke betekenis van Veblen als de manieren waarop het concept is toegepast in de (culturele) criminologie en studies naar hiphop. Vervolgens lichten we onze methoden van onderzoek toe, waarbij we ingaan op de selectie van de rapalbums en de analyse van de rapteksten, en geven we een overzicht van de belangrijkste empirische resultaten. We besluiten met een conclusie waarin we reflecteren op de uitkomsten en we enkele suggesties doen voor vervolgonderzoek naar rapmuziek van Nederlandse bodem.

2 Onze selectie van deze negentien releases, waarbij we naast volledige albums ook zogenaamde mini-albums of EP's hebben meegenomen, lichten we nader toe in de methodologische verantwoording. Omwille van de leesbaarheid zullen we over het algemeen gebruikmaken van de term album, ook wanneer we naar EP's verwijzen. 


\section{Conspicuous consumption}

Toen Thorstein Veblen eind negentiende eeuw schreef over consumptiepatronen binnen verschillende typen samenlevingen zette hij zich af tegen de tot dan toe heersende, rationele visie op economisch handelen. Binnen de neoklassieke economische benadering werd verondersteld dat individuen, met de middelen die zij tot hun beschikking hebben, streven naar nutsmaximalisatie, ingegeven door exogene factoren (Trigg, 2001). De benadering van Veblen plaatste nut echter niet langer centraal, maar zag het economisch handelen van individuen, en daarmee ook hun consumptievoorkeuren, als 'determined socially in relation to the positions of individuals in the social hierarchy' (Trigg, 2001: 99).

In de in toenemende mate geïndustrialiseerde samenleving werd het relatieve belang van welvaart en het bezit van goederen als steeds belangrijker beschouwd. Meer welvaart, verkregen uit arbeid of overerving, leverde een betere reputatie op en zorgde voor meer waardering vanuit de gemeenschap, of in de woorden van Veblen (2017: 19) 'the possession of wealth confers honour'. Het zogenaamde 'oud geld' van aristocratische families leverde daarbij de meeste status op (Veblen, 2017: 22). Deze families hadden veel welvaart, maar hun 'afstand' tot daadwerkelijke arbeid was erg groot; zij hoefden namelijk niets te doen voor hun vermogenskracht. Centraal in het werk van Veblen (2017: 26) staat met name het tonen van welvaart: '[I]n order to gain and to hold the esteem of men it is not sufficient merely to possess wealth or power. The wealth or power must be put in evidence, for esteem is awarded only on evidence.' Deze 'pecuniary strength' en de status die daarmee gemoeid ging had, met andere woorden, een sterk performatief karakter en was afhankelijk van de waardering van anderen (Trigg, 2001: 100-101).

In de oorspronkelijk analyse van Veblen (2017: 63) kan 'echte' welvaart afgelezen worden aan 'verspilling'. Het kan hierbij gaan om de verspilling van vrije tijd, maar ook om verkwisting van goederen. Een voorbeeld van dit laatste kan worden gevonden in consumptie van overbodige goederen of van luxegoederen die meer kosten dan ze waard zijn. Wanneer gemeenschappen echter groter worden, de middelen van communicatie veranderen en de mobiliteit toeneemt, wordt de verspilling van vrije tijd steeds minder zichtbaar en wordt de 'ostentatious display and waste of status-enhancing goods' (Tilman, 2006: 97) - ook wel aangeduid als 'conspicuous consumption' - steeds belangrijker. Naast het munten van de term 'conspicuous consumption', is het deze aandacht voor de vraag wat het gedrag van consumenten zegt over hun sociaaleconomische positie waarin de kern van de sociologische contributie van het werk van Veblen is gelegen (Currid-Halkett et al., 2018: 84). ${ }^{3}$

3 Op de meer dan een eeuw oude benadering van Veblen is in de loop der jaren de nodige kritiek geuit, waaronder het ontbreken van samenhangende empirisch te testen hypotheses, het leggen van te veel nadruk op het trickle down-effect van consumptiepatronen en luxe goederen, het hebben van (te) weinig oog voor meer subtielere uitingen van welvaart en, ten slotte, dat consumptiepatronen niet langer bepaald worden door sociale klassen, maar door levensstijlen die losstaan van sociale hiërarchie (zie o.a. McIntyre, 1992; Trigg, 2001). 
In de (culturele) criminologie valt de invloed van het werk van Veblen te herkennen in analyses van 'consumption-based economies' (Ilan, 2015: 44), zonder dat hier altijd expliciet naar wordt verwezen. Exemplarisch in dit opzicht is de etnografische studie van Nightingale (1993) naar arme Afro-Amerikaanse jongeren in Philadelphia, waarin Nightingale (1993: 135) schrijft over 'the values of conspicuous consumption, as well as the material trapping of those values'. De invloed van het werk van Veblen doet zich hier nadrukkelijk voelen, maar wordt niet benoemd; een bevestiging van de constatering van Campbell (1995: 38) dat de term 'conspicuous consumption' is verworden tot een common-sensebegrip. Op gedetailleerde wijze geeft Nightingale (1993: 135-165) een historisch overzicht van 'American abundance' in de arme achterstandswijken van de Verenigde Staten. Mede als gevolg van gerichte marketingcampagnes beschrijft Nightingale (1993: 153) 'commodity worship' en dat er een groot en emotioneel belang werd gehecht aan materialisme: 'Already at five and six, many kids in the neighborhood can recite the whole canon of adult luxury - from Gucci, Evan Piccone, and Pierre Cardin, to Mercedes and BMW.'

De historische analyse van Nightingale vormde een belangrijke inspiratiebron voor Jock Youngs $(2003,2007)$ boulimia van het sociale systeem. Analoog aan het ziektebeeld boulimia, waarbij terugkerende vreetbuien gepaard gaan met purgerende bewegingen, of andere maatregelen die de overmatige voedselinname compenseren, stelt Young $(2003,2007)$ dat de sociale orde burgers zowel 'opslokt' als 'uitkotst'. In dit proces is het probleem volgens Young (2003: 39) niet zozeer gelegen in 'the full immersion in the American Dream', maar vooral - zoals Nightingale (1993) ook illustreert - dat culturele insluiting in de Amerikaanse (massaconsumptie)cultuur voor velen parallel liep aan ervaringen met zowel ruimtelijke, sociale als economische vormen van uitsluiting. 'Clothes and other conspicuous commodities' worden hierbij volgens Nightingale (1993: 154-155) gezien als manier om met de ervaren strain om te gaan, omdat deze goederen 'offer protection from poverty-based humiliation but also help kids overcome race-based feelings of inadequacy'. Anders dan in de duiding van Veblen gaat het in deze contemporaine beschouwingen niet alleen om 'conspicuous consumption' als demarcatieproces, maar verwordt opzichtig consumeren tot magische oplossing in een zoektocht naar inclusie (Hayward, 2004: 182; Young, 2009).

Alhoewel de consumentenmarkt, anders dan de arbeidsmarkt, een 'easy and universal entry' (Young, 2007: 52) biedt, is het beschikken over (voldoende) bronnen van inkomsten wel noodzakelijk om opzichtig te kunnen consumeren. In studies naar straat- en gangculturen komt naar voren dat, zoals Hallsworth (2013: 153) stelt, met deze spanning op mertoniaanse wijze wordt omgegaan middels 'adaption through innovation'. De informele economie kan hierbij inkomsten genereren, maar zowel Hallsworth (2013: 153-154) als Ilan (2015: 89) wijst op een breed palet aan economisch gemotiveerde vormen van (straat)criminaliteit om voldoende geld te verwerven om daadwerkelijk opzichtig te kunnen consumeren. Naast informele en illegitieme middelen wordt er ook gewezen op een alternatief, innovatief middel: het maken van rapmuziek. Maar, zo merkt Hallsworth (2013: 154) op, het is slechts weinigen gegeven om met rapmuziek daadwerkelijk buiten- 
sporig veel geld te verdienen, ondanks dat 'rapping your way to financial success is a potent ghetto narrative'.

Naast het maken van muziek om meer dan voldoende inkomsten te verwerven om opzichtig te kunnen consumeren, komt het thema van 'conspicuous consumption' op verschillende manieren tot uitdrukking in de bredere hiphopcultuur, onder andere in een breder narratief waarin rappers uiting geven aan kapitalisme en economische begrippen (Rehn \& Sköld, 2005). Studies waarbij de relatie tussen hiphop en consumptie naar voren komt, richten zich echter vooral op Amerikaanse rapmuziek (zie o.a. Rehn \& Sköld, 2005; Hunter, 2011; Podoshen et al., 2014). Uit onderzoek van Podoshen et al. (2014) blijkt dat luisteraars van hiphop een hogere mate van materialisme ervaren dan mensen die de voorkeur geven aan andere muziekgenres. Daarnaast laten luisteraars van hiphop positievere attitudes zien tegenover opzichtige consumptie. Een bekende manifestatie hiervan valt te herkennen in de zogenaamde 'blingbling cultuur' waarin rappers uitbundige sieraden dragen en opscheppen ('boasting') over de waarde van deze kettingen, horloges en ringen (Rehn \& Sköld, 2005).

In andere onderzoeken ligt het accent op de gevolgen van de toegenomen populariteit van hiphop in de Verenigde Staten vanaf de jaren 1990 (Hunter, 2011). Niet langer staan de verhalen over racisme, armoede en ongelijkheid centraal binnen het genre, maar verwordt hiphop in toenemende mate tot een lifestyle die te consumeren valt. Tijdschriften, parfums, schoenen, videospellen en pornografie overspoelen de markt. Grote bedrijven sluiten deals met bekende rappers zoals Jay- $Z$, Diddy, Kanye West of 50 Cent, die hun producten aan de man brengen. ${ }^{4}$ Ook in de teksten en videoclips van rappers valt een ontwikkeling waar te nemen, waarbij verhalen over ongelijkheid en sociale uitsluiting plaats maken voor verhalen over goederen en producten (Hunter, 2011).

\section{Selectie, analyse en interpretatie van rapteksten van Nederlandse bodem}

De wetenschappelijke inzichten over opzichtig consumeren in studies naar hiphop, en straatculturen in bredere zin, roepen de vraag op hoe deze thematiek tot uitdrukking komt in rapmuziek van Nederlandse bodem. Om onze overkoepelende onderzoeksvraag naar de aard en betekenis van opzichtig consumeren in Nederlandstalige rapmuziek te beantwoorden, hebben we recente albums van de meest populaire Nederlandse rappers geanalyseerd. Geïnspireerd door eerdere analyses van Amerikaanse rapalbums (o.a. Kubrin, 2005; Kubrin, 2006; Hunter, 2011) zijn we op zoek gegaan naar openbaar beschikbare overzichten van verschenen rapmuziek van Nederlandse bodem. Onze uiteindelijke selectie is gebaseerd op een door de NOS eind december 2018 gepresenteerd overzicht over de streamingcijfers van Nederlandse rapartiesten in het jaar 2018 (Duijsings \& Van Niekerk, 2018). Om deze lijst samen te stellen kregen journalisten van de NOS

4 Hunter (2011) benoemt dat het door rappers noemen van merknamen in hun teksten in de Verenigde Staten ook het gevolg kan zijn van betaalde product placement. Hoewel het niet uit te sluiten valt dat dit bij Nederlandse rappers ook gebeurt, hebben wij geen bewijs gevonden waaruit dit blijkt. 
van streamingsdienst Spotify toegang tot de exclusieve cijfers over de hoeveelheid streams van Nederlandse rappers. Op basis van deze informatie kwamen zij tot een lijst van de negentien meest populaire rappers, gemeten aan de hand van de hoeveelheid streams op Spotify.

Van deze negentien artiesten hebben wij op 1 oktober 2019 de meest recent verschenen releases geselecteerd voor onze inhoudelijke analyse van de teksten. Tabel 1 geeft een overzicht van de artiesten, albums of EP's, het verschijningsjaar, de hoeveelheid nummers, de (totale) duur van de albums en de hoeveelheid unieke luisteraars op Spotify. De keuze voor deze releases is ingegeven door een aantal factoren. Allereerst hebben wij ervoor gekozen om alle negentien rappers op de overzichtslijst te selecteren om een zo divers mogelijk beeld te kunnen schetsen van rapmuziek van Nederlandse bodem. Ten tweede hebben wij alleen het meest recente album, ${ }^{5}$ of de meest recente $\mathrm{EP}$, meegenomen in onze analyse, vanuit het idee dat straatcultuur bij uitstek veranderlijk is en, daardoor, het van belang is om up-to-date te zijn (El Hadioui, 2011: 19). Daarnaast werd ook onze keuze voor het meest recente werk van deze artiesten ingegeven door het belang dat wij hechten aan het schetsen van een zo breed mogelijk beeld van de populaire Nederlandse rapmuziek. Binnen dit brede beeld is getracht zo veel mogelijk diepgang te vinden in het werk van de artiesten en daarom zijn enkel albums en EP's meegenomen en geen losse singles. Uiteindelijk hebben we de teksten van 283 unieke nummers geanalyseerd, goed voor in totaal 849 minuten muziek. ${ }^{6}$

Een nadrukkelijke vertekening in onze selectie betreft de selectie op basis van populariteit van de rappers. In de bredere hiphopscene, maar ook bij muziek in het algemeen, wordt belang gehecht aan authenticiteit en worden rappers die meer commerciële muziek maken gezien als 'sell out' (Wermuth, 2002; Roks, 2020). Hunter (2011: 20) presenteert, in navolging van Kubrin (2005, 2006), echter overtuigende argumenten om de aandacht in wetenschappelijke analyse nu juist wel te richten op 'best-selling hip-hop because it is the soundtrack of many people's lives, especially those of young people'. Naast het feit dat deze populaire rapalbums zicht geven op de huidige trends en ontwikkelingen, hebben de negentien rappers in onze selectie, afgaande op de miljoenen streams op Spotify, veel fans en een grote afzetmarkt. Hierdoor kunnen zij ook veel invloed hebben op jonge luisteraars, want 'young people internalize these highly repetitive scripts and often use them to understand their own and others' lives' (Hunter, 2011: 31).

Om de teksten te verzamelen van de nummers op de door ons geselecteerde negentien albums, hebben we gebruikgemaakt van de website https://genius.com. Meer dan honderd miljoen gebruikers, waaronder muziekconsumenten, -produc-

5 Albums die na 1 oktober 2019 zijn verschenen, de start van onze dataverzameling en -analyse, hebben we niet opgenomen in onze selectie.

6 Eerdere wetenschappelijke studies waarin gebruik is gemaakt van rapmuziek geven geen eenduidig beeld van de hoeveelheid geanalyseerde nummers. Kubrin (2006) baseert zich in haar analyse van Amerikaanse gangsta rap in de periode 1992-2000 op 403 nummers, in totaal 1.588 minuten aan muziek, maar signaleert tevens dat ze rond de 350 nummers al tot saturatie kwam. In de studie van Hunter (2011) is aanzienlijk minder bestudeerd, te weten 30 nummers en 41 video's van rapnummers. 
Tabel 1 Overzicht geanalyseerde albums

\begin{tabular}{|c|c|c|c|c|c|}
\hline & $\begin{array}{l}\text { Naam } \\
\text { artiest/ } \\
\text { groep }\end{array}$ & Naam album en jaartal & $\begin{array}{l}\text { Hoe- } \\
\text { veel- } \\
\text { heid } \\
\text { num- } \\
\text { mers }\end{array}$ & $\begin{array}{l}\text { Tijds- } \\
\text { duur } \\
\text { totaal } \\
\text { (in } \\
\text { minu- } \\
\text { ten) }\end{array}$ & $\begin{array}{l}\text { Hoeveelheid unieke } \\
\text { luisteraars per maand* }\end{array}$ \\
\hline I. & Josylvio & Gimma (2019) & 16 & $43: 59$ & 1.486 .191 \\
\hline 2. & Ronnie Flex & Nori (2018) & 13 & $35: 58$ & I.837.573 \\
\hline 3. & Lil Kleine & Alleen (2017) & 21 & $77: 00$ & 2.179 .877 \\
\hline 4. & Bizzey & Tido (2019) & 19 & $52: 44$ & 2.224 .501 \\
\hline 5. & Boef & $93(2019)$ & 11 & $31: 11$ & I.287.233 \\
\hline 6. & Frenna & Francis (Deluxe) (2019) & 21 & $61: 00$ & 1.934 .943 \\
\hline 7. & $\begin{array}{l}\text { Broeder- } \\
\text { liefde }\end{array}$ & We Moeten Door 2 (2018) & 15 & $52: 32$ & 1.063 .696 \\
\hline 8. & Sevn Alias & Sirius (2019) & 16 & $47: 48$ & 1.339 .269 \\
\hline 9. & SFB & Reset The Levels III (20I8) & 12 & 39:11 & 616.984 \\
\hline 10. & SBMG & Metro 53 (2018) & 14 & $45: 51$ & 706.995 \\
\hline 11. & Lijpe & Fastlife (2019) & II & $35: 07$ & 579.705 \\
\hline 12. & $\begin{array}{l}\text { Kraantje } \\
\text { Pappie }\end{array}$ & Daddy (20।8) & 18 & $54: 01$ & 1.493 .765 \\
\hline 13. & Kevin & Vrij (2019) & 15 & $44: 17$ & 739.514 \\
\hline 14. & Ali B & $\begin{array}{l}\text { Een Klein Beetje Geluk } \\
(2016)\end{array}$ & 15 & $43: 58$ & 1.084 .758 \\
\hline 15. & Jonna Fraser & Lion (20I8) & 15 & $44: 24$ & I.227.393 \\
\hline 16. & Mula B & Meesterplusser (2018) & 12 & $38: 24$ & 1.317 .900 \\
\hline 17. & Jaccin Trill & Happyland 2.0 (2018) & 13 & $25: 00$ & 284.348 \\
\hline 18. & Hef & Koud (2019) & 14 & $40: 40$ & 729.813 \\
\hline \multirow[t]{2}{*}{19.} & Esko & Beats By Esko (2018) & 12 & $36: 16$ & 830.516 \\
\hline & Totaal & & 283 & $849: 35$ & 19.801 .433 \\
\hline
\end{tabular}

* Volgens Spotify (per 19/12/2019)

ten en -labels, wereldwijd maken gebruik van dit platform om favoriete nummers en teksten te bespreken en te deconstrueren. Dit 'collective music IQ', zoals de website stelt, resulteert in een kennisdatabank van meer dan 25 miljoen nummers, teksten en artiesten. Alle teksten van de door ons geselecteerde albums konden integraal gevonden worden via deze website. Per album werden alle teksten van alle nummers geselecteerd en opgeslagen. $\mathrm{Na}$ deze dataverzameling werden de rapnummers beluisterd en vergeleken met de verbatim weergave van de teksten afkomstig van genius.com. Slechts heel sporadisch constateerden wij daarbij een verschil tussen de muzikale en uitgeschreven weergave van de nummers. Bovendien kent de website als service dat in sommige nummers metaforen en 'slang' van een duiding in een annotatie worden voorzien, veelal door luisteraars van de muziek. 
Omwille van de betrouwbaarheid van de analyse hebben we, in navolging van Kubrin (2005, 2006) drie volledige albums, te weten Gimma (2019) van Josylvio, Reset the Levels III (2018) van SFB en Lion (2018) van Jonna Fraser, die willekeurig werden gekozen, intensief beluisterd met de uitgeschreven teksten. Onafhankelijk van elkaar hebben we vervolgens bekeken in hoeverre het thema opzichtige consumptie - in deze fase geoperationaliseerd als 'verwijzingen naar dure goederen en/of merken, bijvoorbeeld in de vorm van auto's, kleding of sieraden' - tot uitdrukking kwam in deze 43 nummers. Tijdens het vergelijken en bespreken van onze resultaten en interpretaties bleken slechts drie van de 43 nummers geen expliciete verwijzingen naar dure goederen of merken te bevatten. Ondanks dat dit illustreert hoezeer opzichtige consumptie een thema is in de door ons bestudeerde nummers, wil dit echter niet zeggen dat er in de teksten geen andere onderwerpen worden behandeld.

$\mathrm{Na}$ deze eerste grove codeerfase hebben we gezamenlijk een thematische codelijst opgesteld op basis van de bestudeerde wetenschappelijke literatuur over 'conspicuous consumption', zowel in de originele formulering van Veblen als in de manier waarop het begrip wordt gebruikt in hedendaagse studies naar straatcultuur en hiphop. Deze codelijst bevatte thematische codes over, onder andere, verwijzingen naar opzichtig consumeren in het algemeen, specifieke vormen van opzichtig consumeren (bijv. auto's, kleding of sieraden), verwijzingen naar merken en de herkomst van de financiële middelen om deze uitgaven mogelijk te maken (Evers, 2015: 92). Na het invoeren van deze codelijst in Atlas.ti hebben we onafhankelijk van elkaar acht albums gecodeerd en vervolgens elkaars manier van coderen en interpretaties vergeleken.

Op enkele (accent)verschillen na, die uitgebreid werden besproken, bleken onze interpretaties goed op elkaar aan te sluiten. Na deze fase van thematisch coderen hebben we open codes toegekend (Evers, 2015: 89), in het bijzonder om daarmee tekstfragmenten te vangen die niet onder onze bestaande codes konden worden geschaard, zoals de term 'stacken': het opstapelen van geld (SMIB, 2017: 168). Daarnaast werden enkele reeds bestaande thematische codes hernoemd om beter aan te sluiten bij de belevingswereld en de gehanteerde terminologie van de rappers. Zo werd de thematische code 'conspicuous consumption - merkkleding' in deze fase vervangen door de code 'drip' en werd 'uitgeven van veel geld' veranderd in 'spenden'. De resultaten van het thematisch en open coderen werden, ten slotte, overstijgend met elkaar in verband gebracht in de vorm van een patroonanalyse (Evers, 2015: 117). Deze laatste stap in onze analyse gaf zicht op de drie hoofdthema's die de structuur vormen van onze empirische bevindingen.

Voordat we deze resultaten ${ }^{7}$ echter nader toelichten, verdient de interpretatie van de rapteksten nog aandacht. Discussies over rapmuziek, zowel binnen de wetenschap (voor een overzicht, zie Roks, 2020) als daarbuiten (zie o.a. Algemeen Dagblad, 1 oktober; de Volkskrant, 23 oktober), worden geplaagd door de vraag in

7 Omdat het onderhavige onderzoek zich toespitst op de muzikale cultuur van exces, belichten we in onze resultaten enkel thema's die gerelateerd kunnen worden aan opzichtige consumptie. Dit neemt echter niet weg dat er ook andere thema's werden behandeld door de rappers, zoals hun relaties met vrouwen, ervaringen met uitsluiting en criminaliteit en geweld. 
hoeverre de teksten en uitspraken van de rappers gezien kunnen of moeten worden als autobiografisch. We gaan er in onze analyse niet a priori van uit dat er een relatie bestaat tussen de rapteksten en de biografieën van de muzikanten. In sommige gevallen is er wellicht sprake van een overlap tussen de thematiek in de muziek en het persoonlijke leven van rappers, maar de historie van hiphop leert dat de hyperbolen, metaforen en andere door rappers gehanteerde stijlvormen een een-op-eenvertaling in de weg staan (De Roest, 2017; Roks, 2020). Wel laten analyses van Amerikaanse rapteksten (Kubrin, 2005, 2006) zien dat de thema's in de muziek zicht geven op bredere sociale, economische en politieke problemen die zich in de belevingswereld van de rappers afspelen. Sterker nog, Pattillo-McCoy (1999: 121) stelt dat 'these stories are also told by sociologists, anthropologists, and historians, but devoid of the emotion'. Dit maakt de teksten niet per definitie waar, authentiek of autobiografisch, maar voor wetenschappers wel een bijzonder waardevolle aanvulling op meer directe methoden van dataverzameling.

\section{Aard en betekenis van opzichtige consumptie in Nederlandstalige rap}

Onze analyse van de negentien rapalbums van Nederlandse bodem gaf zicht op een drietal overstijgende patronen rondom opzichtige consumptie. Allereerst springt in het oog hoezeer de teksten van de rappers doordrenkt zijn met verwijzingen naar geld, alsmede de manieren waarop geld door de rappers gegenereerd wordt. Daarnaast komt het belang dat door de rappers aan geld wordt gehecht ook tot uitdrukking in het tweede centrale thema: het openlijk en opzichtig demonstreren van vermogen, ofwel door het laten zien van grote stapels contant geld, maar ook door het veelvuldig verwijzen naar het uitgeven van geld aan diverse luxegoederen. Als laatste overkoepelende onderwerp behandelen we de beschrijving van de beweegredenen die door de rappers zelf worden gegeven voor het door hen tentoongespreide materialisme.

\section{'Ik ben op papier': het belang van het genereren van geld}

In de teksten van de door ons bestudeerde nummers is 'geld' het leidmotief. We zien dit onderwerp op diverse manieren naar voren komen en ook in verschillende aanduidingen. Naast de generieke aanduiding 'geld', en de Engelse vertaling 'money', komt in de teksten naar voren dat rappers 'op cash', 'op paper', 'op papier', 'op munten', 'op dough'8 of 'op cake' zijn. De overduidelijke invloed van Amerikaanse straattaal, populair geworden via de tonen van de mondiale hiphopcultuur, gaat ook gepaard met Spaanse verwijzingen naar geld als 'dinero', 'mula' of 'guap'. Daarnaast zien we ook meer lokale straattaal naar voren komen in het gebruik van het Surinaamse woord 'doekoe' en de uit het Arabisch afkomstige

8 In het gebruik van het woord 'od', de omgekeerd geschreven verbastering van het woord 'dough', zien we dat jongeren zich ook laten inspireren door straattaal dichter bij huis: het verlan dat gesproken wordt in de Franse banlieues (Slooter, 2015: 49). 
woorden 'floes' en 'saaf'. Dit uiteenlopende monetaire lexicon ${ }^{9}$ verraadt, zoals El Hadioui (2011: 33) constateert, dat de taal van de rappers een reflectie vormt van hun voorkeuren.

Het belang dat de rappers hechten aan het onderwerp geld vertaalt zich allereerst in de communicatie van een meer algemene aantrekkingskracht en motivatie ten aanzien van geld die zich op betekenisvolle wijze laat vangen in de uitspraak 'money on my mind' ${ }^{10}$ Variaties hierop zien en horen we terug in zinnen als 'willen die dough, willen die dough'11 en ' $\mathrm{ik}$ ben op papier'. ${ }^{12}$ In deze bovengenoemde voorbeelden wordt rondom het generieke verlangen naar geld niet nader gespecificeerd hoe dit verkregen zou moeten of kunnen worden. Hierin valt een meer algemeen straatimperatief waar te nemen dat door Hallsworth (2013: 152-156) wordt omschreven als 'the search for money'.

Analoog aan de inzichten uit studies over straatcultuur, verhalen de rappers in hun nummers echter ook dat deze zoektocht naar geld op straat veelal op semilegale en vaak op illegitieme wijze wordt ingevuld. Het volgende refrein van een nummer van Hef is wat dat betreft illustratief:

\section{'Ik zoek die cake}

Ik kan niet bouwen op mensen want mensen zijn fake

Soms lijkt het net of ik gek word, ik zeg het je straight

Ik pak het, ik spend het, we rennen dit is hoe ik leef

Ik hossel, ik hossel, ik hossel, wanneer zijn we safe? ${ }^{\text {13 }}$

De term 'hosselen' in de bovenstaande rap kan aan de ene kant gelezen worden als een verbastering van hustling, een term die in de Verenigde Staten uitdrukking geeft aan overlevingsstrategieën van de arme, stedelijke bevolking. Het woord hustlin(g) is populair geworden door de mondiale hiphopcultuur (vgl. Brown, 2010), maar kent in de Nederlandse context ook een invloed vanuit Suriname. Daar wordt 'hosselen' in verband gebracht met 'pinaren', oftewel armoede lijden, en wordt het eveneens beschouwd als overlevingsstrategie op straat, die verschillende vormen kan aannemen, waaronder semilegale en illegitieme manieren van geld verdienen (Buiks, 1983; Sansone, 1992). In de teksten van de rappers lijkt 'hosselen' echter een verwijzing te zijn naar criminele activiteiten, iets dat wordt geëxpliciteerd in de vorm van verwijzingen naar inbraken ('oeffoeboys'14) of naar

9 De rappers in onze analyse verwerken bovendien diverse valuta - euro's, dollars en ponden - en verschillende aanduidingen van de hoeveelheid geld, zoals 'm's' (miljoenen), 't'tjes' (tonen), specifieke bedragen eindigend op 'k' (naar het Amerikaanse gebruik van de letter 'k' voor 'kilo'), maar ook de uit het Surinaams afkomstige hoeveelheden als 'barkie' (100).

10 Sevn Alias ft. Josylvio - ‘Gangsta Boppin' (2019).

11 Frenna ft. Josylvio - 'VVS' (2019).

12 SBMG ft. D-Double, Mani \& Josylvio - 'Herres' (2018).

13 Hef ft. Crooks - 'Wanneer zijn we safe' (2019).

14 Lijpe ft. Joey AK - 'Vast in die trap' (2019). 
het dealen van drugs ('was in de buurt met wit en ik dacht ik zou in coke gaan'15 en 'we seren die wiet en die hasj'16).

De groeiende populariteit van Nederlandstalige rapmuziek heeft als direct gevolg dat de rappers in toenemende mate ook op een legale wijze hun geld (kunnen) verdienen, of zoals Boef rapt: 'Ik kan millies maken door teksten schrijven'. ${ }^{17} \mathrm{Dit}$ is een wezenlijk verschil met de tijd dat rappers nog afhankelijk waren van de verkoop van fysieke albums en gedraaid werden op de radio. Het overzicht in tabel 1 illustreert dat de muziek van rappers in deze selectie op Spotify veel gestreamd wordt, of zoals Kraantje Pappie stelt: 'Streams in de miljoenen ' $t$ is bewezen niet eenmalig'. ${ }^{18}$ Ondanks de voor rappers positieve ontwikkeling van het digitaal kopen en streamen van muziek, is het de vraag of het verdienmodel van Spotify - of streamingdiensten meer in het algemeen - zo lucratief zijn. Raatgever (2019) stelt dat een miljoen streams ongeveer $€ 1300$ zouden opleveren. Dit levert wellicht maandelijks een mooie som geld op, maar is niet direct genoeg om de hang naar geld echt te kunnen bevredigen. Volgens de rappers zelf zit het echte grote geld in 'show money': de opbrengsten van optredens. Ali B geeft hiervan een voorbeeld:

'Bel de baas van een multinational en zeg hem luister jongen

Binnenkort treed ik op bij je bedrijfsfeest

Tien $\mathrm{K}$ is minimaal wat je aan mij geeft. ${ }^{\text {'19 }}$

Als rapper, maar vooral ook vanwege zijn status als Bekende Nederlander, kan Ali B met $€ 10.000$ per boeking ('Tien K') gezien worden als grootverdiener. Deze 'show money' kan, afhankelijk van populariteit en de hoeveelheid toekenningen, voor rappers veel geld opleveren.

In de door ons bestudeerde teksten zien we dat muziek als bron van inkomsten door sommige rappers wordt gerelateerd aan hun verleden met het verdienen van geld op straat. Exemplarisch in dit opzicht zijn de uitspraken 'vroeger crack koken, nu betaalt rap mij'20 en 'we maken money nu met liedjes, maar vroeger was ik een dief. ${ }^{21}$ Onafhankelijk van de legale of illegale herkomst van de verkregen financiële middelen, rijst er een duidelijk beeld van de inspanningen die de rappers zich hebben getroost. Zo rapt Kevin: 'Op de grind, anders winnen we nooit'. ${ }^{22}$ De term 'grinden', Amerikaans slang dat in verband wordt gebracht met hosselen en impliceert dat er hard gewerkt moet worden, komt naar voren op veertien van de negentien door ons bestudeerde albums. ${ }^{23}$ Anders dan in de origi-

Boef - 'Streetlife' (2019).

SBMG ft. Lil Kleine - 'Gedrag' (2018).

Boef - 'Schilderij' (2019).

Kraantje Pappie - 'Controle’ (2018).

Ali B ft. Glen Faria - 'Gekke kleine jongen' (2016).

Josylvio - 'Game over' (2019).

Bizzey ft. Josylvio \& kans - 'Baila mami’ (2019).

Kevin - 'Geen Beveiliging' (2019).

Op de albums van Ali B, Broederliefde, Jacin Trill, Kraantje Pappie, Mula B wordt de term 'grin-

den' niet gebruikt. 
nele analyse van Veblen beschrijven de rappers hiermee dat het geld hun niet komt aanwaaien, maar dat ze er flink voor hebben moeten werken.

\section{'Double die stack, we blowen die money': over spenden en stacken}

Het tweede overkoepelende thema in de analyse van negentien rapalbums ziet op de manieren waarop de rappers het verkregen geld uitgeven. De consumptie van de rappers kan worden gekarakteriseerd als (bijzonder) opzichtig en eveneens, in lijn met Veblens interpretatie van 'conspicuous consumption', als verspilling. Frenna geeft hier een voorbeeld van wanneer hij rapt: 'Ik heb wat boys in de trap en ze vouwen die packs. Double die stack, we blowen die money, maar pakken het back'. ${ }^{24}$ Naast dat Frenna met de woorden 'trap' en 'vouwen die packs' verwijst naar respectievelijk een drugspand (Storrod \& Densley, 2017) en voorbereidingshandelingen voor het verkopen van cocaïne, komt het summum van de verkwisting van geld tot uitdrukking in 'we blowen die money'. Deze verbastering van het Amerikaanse slang 'blowing money' verwijst naar het uitgeven van grote hoeveelheden geld aan verschillende goederen en diensten. Een ander Amerikaans leenwoord dat veelvuldig in het vocabulaire van de rappers naar voren komt als het gaat om hun consumptiegedrag is de term 'spenden'. Lil Kleine verwijst bijvoorbeeld naar zichzelf als 'je boy Big Spend' ${ }^{25}$ om aan te geven dat hij veel geld uitgeeft, terwijl Jacin Trill rapt: 'Ik moet altijd tennissen want ik word weer te rijk, dus ik spendeer money nu net als een sjeik'. ${ }^{26}$

Naast frequent terugkerende algemene verwijzingen naar het 'blowen' en 'spenden' van geld, maken de rappers in hun teksten ook kenbaar aan welke specifieke goederen, producten of diensten ze hun geld uitgeven. De specifieke uitgaves die naar voren kwamen op de albums van de artiesten betroffen het uitgeven van geld aan vrouwen in de vorm van het betalen van een vakantie of het kopen van kleding, het uitgeven van geld in het uitgaansleven aan drank en eten, al dan niet in gezelschap van (grote) groepen vrienden, het aanschaffen van dure auto's en het kopen van merkkleding en -schoenen en luxe sieraden, waaronder horloges, kettingen, armbanden en zonnebrillen. Het voert te ver om alle voorbeelden afzonderlijk te illustreren, te meer omdat deze uitgaven opvallend vaak in samenhang werden beschreven, zoals door Josylvio: 'Stoelverwarming in de stoelen, we liggen nu lager, nieuwe outje, nieuwe klokkie, we shoppen nu vaker In m'n trinna in je restaurant, money kan praten' ${ }^{27}$ Naast deze generieke aanduiding van producten, sprongen met name ook verwijzingen naar dure merken in het oog. De meest aangehaalde merken waren Mercedes Benz (73 keer), ${ }^{28}$ Louis Vuitton (55

28 Atlas.ti beschikt over een analysefunctie om de frequentie van woorden in de geanalyseerde tekst te genereren. In het samenstellen van de totale frequentie hebben we rekening gehouden met de verschillende manieren waarop er naar een merk kan worden verwezen. Mercedes Benz werd door de rappers bijvoorbeeld aangeduid als zowel 'Merry/Merrie' als ‘Benz'. 
keer), Range Rover (53 keer), Gucci (47 keer), Rolex (30 keer), Louboutin (24 keer), Dita (18 keer) en Balmain (12 keer). ${ }^{29}$

In onze analyse stuitten we op een terugkerende term die aan de kern van opzichtig consumeren raakt: 'drip'. Op het nummer Drip horen we 'Now watch me drip, fully GG, want ik ben lit' ${ }^{30}$ en op het album van Esko rapt Sevn Alias: 'VVS's en die Merry. Kijk hoe ik van de bottom tot de top drip'. ${ }^{31}$ In beide voorbeelden herkennen we dure merken: van een auto ('Merry Benz'), van kleding ('Fully GG', oftewel de bekende twee letters ' $G$ ' van het merk Gucci) of van diamanten met hoge kwaliteit ('VVS's'). De betekenis van 'drippen' valt af te leiden uit de manier waarop de term door de rappers gebruikt wordt. 'Drip' kan gebruikt worden als een verwijzing naar de outfit, of beter het algemene voorkomen, van een persoon, maar in veel gevallen lijkt het over meer te gaan. 'Drippen' moet dan in overdrachtelijke zin gezien worden als vloeistof die van een persoon - in dit geval een rapper afdruipt vanwege de 'hitte' die zijn voorkomen uitstraalt, in het bijzonder door de dure, exclusieve merkkleding en -schoenen en fonkelende sieraden die hij draagt. We herkennen hierin een parallel met de term 'schijnen' - van het Amerikaanse 'shinen' - dat op straat gebruikt wordt als verwijzing naar het openlijk pronken met dure merkartikelen en luxe sieraden (De Jong, 2007: 164-165).

Ondanks dat opzichtig consumeren in de vorm van het tonen van dure goederen van exclusieve merken beschouwd kan worden als het dominante narratief in de door ons bestudeerde teksten, horen we in enkele nummers een tegengeluid. Een voorbeeld hiervan vinden we bij Hef die de volgende reflexieve vragen opwerpt: 'Wat heb je aan die Louis tasje als die tasje leeg is? Wat heb je aan een jas van Gucci als die jas geleend is?'32 Ook Kevin snijdt een vergelijkbaar onderwerp aan met de woorden: 'Mams is skeer, maar bosst je money in clubs. Indruk maken op je bitch van net 18 plus'. ${ }^{33}$ Beide rappers benoemen en problematiseren hier de opzichtige consumptie, waarbij uiterlijk vertoon (letterlijk) de boventoon voert en het vooral lijkt te gaan om het wekken van een goede, succesvolle indruk. De (financiële) realiteit van veel rappers, maar ook van jongeren op straat, is echter minder rooskleurig.

Deze nadruk op het performatieve karakter van 'conspicuous consumption' lijkt voor Hef de aanleiding te zijn om te rappen: 'Niet spenden op die bullshit, nigga stash gewoon'. ${ }^{34}$ In deze context kan het woord 'stash' vertaald worden als opslaan en, daardoor, als sparen, iets dat haaks lijkt te staan op de hedonistische levensstijl van de straat (Ilan, 2015: 16) die in veel van de door ons bestudeerde albums naar voren komt. We zien een vergelijkbare omgang met geld tot uiting komen in het door de rappers veelgebruikte 'stacken'. Uit de teksten van de rappers kunnen we afleiden dat 'stacken' geïnterpreteerd kan worden als het letterlijk stapelen van geld. Dit 'stacken' van geld komt op de door ons bestudeerde Phillipe en Off-White een enkele keer genoemd.

30 SFB ft. Dopebwoy en Leafs - 'Drip' (2018).

31 Esko ft. Sevn Alias \& Josylvio - 'Dichterbij' (2018).

32 Hef - 'Niks' (2019).

33 Kevin ft. Bizzey - 'Zielige gozer' (2019).

34 Hef - 'Morgen is niet beloofd' (2019). 
albums op twee manieren naar voren. Allereerst herbergt 'stacken', net als 'spenden', een duidelijk showelement, zoals we horen in 'We tellen en gooien met stacks. 100tjes, 50'jes yes'35 of in 'Zie me zwaaien met die bom. Leg die stack daar neer. En ik zei dat ik kom'. ${ }^{36}$ In beide gevallen verwijst de term 'stack' hier naar een stapel contant geld, waarbij rappers in hun teksten op diverse manieren proberen aan te duiden dat hun stapel van een goede, indrukwekkende omvang is, bijvoorbeeld in de vorm van 'stack hoog', 37 'stack lang'38 of een 'dikke stack'. ${ }^{39}$

In het gebruik van de term 'stacken' valt echter ook een spaarelement te ontwaren, zoals bij Josylvio, die naast veelvuldige verwijzingen naar een exorbitant consumptiepatroon, rapt: 'Stack die money voor mijn kids'. ${ }^{40}$ Op het nummer \#LIFEGOALS rapt Jonna Fraser iets vergelijkbaar, wanneer hij richting een (potentiële) vriendin stelt: 'Ik ben aan het sparen voor een huis'. Dit sparen van geld in plaats van het direct uitgeven lijkt, op basis van de teksten die wij hebben geanalyseerd, in de belevingswereld van de rappers echter een ondergeschikte rol te spelen. Lijpe neemt de luisteraar mee in die belevingswereld en adresseert de spanning tussen 'spenden' en 'stacken': 'Nu kan ik die bom trekken, of zal ik die bom stacken? Hey, ik ken die grijze dagen toen ik rood stond'. ${ }^{41}$ Het benoemen van het verleden waarin geld voor veel rappers een punt van zorg lijkt te zijn geweest, is het derde en laatste overkoepelende thema in de analyse van de rapalbums.

'Zeg waar was je toen we stonden in de regen?': de betekenis van opzichtig consumeren Naast het etaleren van 'spenden' en 'stacken' geven de teksten ook zicht op de beweegredenen van deze vormen van opzichtig consumeren. Een centraal element waar de rappers naar verwijzen, is de lange weg die zij hebben moeten afleggen om te komen waar zij 'nu' zijn. Ze expliciteren daarbij een proces van sociale mobiliteit, in de vorm van beschrijvingen als 'we gaan omhoog net een rocket' 42 of 'van de bodem naar de top'. ${ }^{43}$ De ontworsteling aan de vroegere situatie en de opwaartse sociale mobiliteit worden door de rappers letterlijk weergegeven als een proces van '(op)klimmen' van een lage sociaaleconomische positie - 'van de bodem' of 'van de goot' - naar 'de top', oftewel naar hoge(re), meer welvarende levensomstandigheden. De uitzichtloosheid van de periode in hun leven waarin ze geen comfortabele leefsituatie kenden, komt tot uitdrukking in woorden als 'struggle' of 'strijd', of zoals Jonna Fraser in het nummer 'Regen' met veel emotie stelt: 'Zeg waar was je toen we stonden in de regen?'44

De 'struggles' waarmee de onderzochte artiesten kampten, zijn verschillend van aard. Thema's als armoede, criminaliteit, stigmatisering, uitsluiting of het ont-

36 Broederliefde - 'LaLaLaLaLa' (2018).

37 Esko ft. Jonna Fraser, Adje, Keizer \& Woenzelaar - 'Kuifje' (2018).

38 Esko ft. Jonna Fraser, Adje, Keizer \& Woenzelaar - 'Kuifje' (2018).

39 Jonna Fraser ft. Jandro - 'Foto' (2018).

40 Josylvio - 'Stoelverwarming' (2019).

41 Boef ft. Lijpe - 'Terug naar toen' (2019).

42 Ronnie Flex ft. Leafs - 'Wat is love' (2018).

43 Frenna - 'Pia' (2019).

44 Jonna ft. Bokoesam \& KM - 'Regen' (2018). 
breken van (goede) rolmodellen passeren in hun teksten veelvuldig de revue. Sommige van de rappers benadrukken vooral één van deze aspecten, terwijl anderen een combinatie van factoren benoemen. De eerste en tevens meest voorkomende 'struggle' in de door ons geanalyseerde teksten is het opgroeien in een situatie van armoede. Zo stelt Ali B dat hij zijn huidige succes bijna niet kan begrijpen als hij kijkt naar vroeger:

'Als je twaalf jaar geleden had gezegd dat dit allemaal gebeuren zou had ik je direct Gestuurd naar de gekkenhuis, ik was skeer

Zat diep in de schulden, nu ben ik miljonair, what the fuck?'45

Armoede was niet alleen een individuele aangelegenheid van de rappers, maar leek een (veelvoorkomend) probleem in hun bredere leefomgeving, of zoals Mula B op het nummer Struggle rapt: 'Niet denken dat het beter gaat. Want m'n buurt die is nog armer dan een ledemaat.'

In veel gevallen worden de ervaringen met armoede van de rappers gekoppeld aan het gezin waarin zij zijn opgegroeid. Met name de moeder van de rappers wordt hierbij veelvuldig aangehaald, zoals door Sjaf, van rapformatie Broederliefde:

'Mijn moeder is tevreden want we komen toch van niets.

Moesten blacka met metro anders kwamen we d'r niet.

Zo van moeders met weinig, toch maakte ze mannen.

Kom van een koelkast met bakjes en pannen'46

Naast sociale mobiliteit als gevolg van de inkomsten van rapmuziek zien we dat rappers met name hun nieuwgevonden financiële voorspoed lijken te willen delen met hun moeder. KM van rapformatie SFB expliciteert dit in de vorm van 'Ik zoek een stack voor m'n moeder'. ${ }^{47}$ Ook herkennen we in veel teksten beschrijvingen waaruit valt af te leiden dat menig rapper afkomstig is uit een gebroken gezin, waarbij één van de ouders afwezig was, of allebei de ouders afwezig waren en de zorg door een ander familielid is overgenomen. ${ }^{48} \mathrm{Bij}$ Hef komt dit treffend tot uiting in: 'Proosten met champagne, heel m'n libi is nu duur. M'n moeder liep te

Ali B ft. Glen Faria - 'Gekke kleine jongen' (2016).

Broederliefde - 'Niet meer terug' (2018).

SFB ft. Rabby Racks - 'Veel toneel' (2018).

In Nederland groeien kinderen in ruim één op de vijf gevallen op in een eenoudergezin (Nederlands Jeugdinstituut via www.nji.nl/nl/Databank/Cijfers-over-Jeugd-en-Opvoeding/Cijfers-peronderwerp/Cijfers-per-onderwerp-Gezinnen). Eenoudergezinnen met minderjarige kinderen lopen het meeste kans op armoede. Wanneer alleen een moeder aan het hoofd van het gezin staat, blijkt dat $16 \%$ van de eenoudergezinnen in armoede leeft. Bij alleen een vader aan het hoofd van het gezin is dit 7,5\% (Sociaal en Cultureel Planbureau via https://digitaal.scp.nl/ armoedeinkaart2018/armoede-bij-kinderen-en-volwassenen). 
stressen, had geen money voor de huur. Enige voorbeelden waren dealers uit de buurt.' 49,50

Een verleden met een gebrek aan geld wordt door veel rappers direct gekoppeld aan hun (vroegere) ervaringen met criminaliteit. Mula B beschrijft deze situatie als 'Maak je geen money broer, dan kan je beter doodgaan. Ben aan het rennen neef, ik denk niet aan een loopbaan'. ${ }^{51}$ Naast het hedonisme dat welig tiert op straat, herkennen we in dit citaat ook kortetermijndenken waarin geld lijkt te prevaleren boven baankansen in de formele economie. Daarnaast komt in de teksten ook tot uitdrukking dat rappers de nodige problemen hebben ervaren in het verkrijgen van toegang tot de arbeidsmarkt, in het bijzonder als gevolg van stigmatisering of discriminatie. Boef - echte naam Sofiane Boussaadia - beschrijft dat als volgt: 'Zet die overval, mannen knallen daar. Kijk m'n achternaam, had geen vaste baan'52 of de vergelijkbare beschrijving van Ali B(ouali): 'Ik werd gelabeld als een crimineel, komt 't door m'n naam ofzo? Of door de torries, want ik had nooit een baan ofzo. 53

Ondanks dat muziek voor veel rappers gezien kan worden als de drijvende kracht achter hun sociale mobiliteit, brengt de transitie van de straat naar de muziek ook een zekere mate van spanning met zich mee. Straatrappers ontlenen immers een belangrijk deel van hun 'street credibility' (Roks, 2013) aan verwijzingen naar criminaliteit en ervaringen op straat, maar hun commerciële en financiële succes voert hen juist (verder) weg van de straat. Doordat de rappers in hun muziek wel (blijven) verhalen over de straat, inclusief specifieke toespelingen op het verdienen van hun geld met criminele activiteiten, is het voor 'buitenstaanders' moeilijk om in te schatten in hoeverre de rappers daadwerkelijk niet langer actief zijn op straat. Mula B verwoordt deze thematiek op een beeldende wijze, wanneer hij, vanuit het perspectief van een agent, rapt: 'Maar je bent nog steeds die crimineel, je weet nog steeds niet wat je wil, je bent nog steeds dezelfde kil. Die nog bezig is met soos, terwijl je money pakt met shows. 54

De fascinatie voor geld, in de vorm van 'spenden' of 'stacken', lijkt dus voort te komen uit spanning tussen legale en illegale wijzen van geld verdienen, tussen het 'goede' en het 'kwade'. Bovenal lijkt het ook een spanning te zijn die ontstaat uit de angst om terug te vallen naar een situatie van armoede, criminaliteit en sociale uitsluiting. Een angst om terug te vallen naar de tijd van 'toen', zonder financiële voorspoed en (maatschappelijk) succes. Dit zien we terug in de tekst van Chivv: 'Ik ben fully fully focussed. Let je niet op, ben je even aan de top. En daarna raak

49 Hef koppelt hier het opgroeien in een gebroken gezin en in een buurt waar armoede alom aanwezig is aan het gebrek aan fatsoenlijke rolmodellen. De relatie tussen armoede en gezondheidsrisico's, bijvoorbeeld het ervaren van chronische stress (Rijksinstituut voor Volksgezondheid en Milieu via www.loketgezondleven.nl/gezonde-gemeente/themadossiers/armoede-schulden-engezondheid/relatie-armoede-en-gezondheid) is veelvuldig onderwerp van onderzoek geweest. Een gebrek aan financiële middelen kan er tevens voor zorgen dat mensen niet de juiste beslissingen nemen door een gebrek aan 'bandbreedte' (vgl. Mullainathan \& Shafir, 2014).

50 Hef - 'Dealers uit de buurt' (2019).

51 Mula B - 'Bandolero' (2018).

52 Boef - 'Rolls sessie' (2019).

53 Ali B ft. Sevn Alias \& Boef - 'Een klein beetje geluk' (2016).

54 Mula B ft. Sticks - 'Aangehouden op een Maandag' (2018). 
je het kwijt', 55 en Jonna Fraser: 'Ja we leven La Vida Loca, ik moet een millie hitten voor ik ontspan'. ${ }^{56}$ Aan 'de top' blijven vereist focus en harde inspanning van de rappers, het bereiken van 'een millie' (een miljoen euro) zal pas soelaas bieden en de zekerheid dat armoede (voorgoed) achter hen gelaten kan worden.

\section{Conclusie}

Dit artikel biedt inzicht in de manier waarop 'conspicuous consumption' tot uiting komt op negentien albums van de in 2018 meest populaire Nederlandstalige rappers en hoe zij in hun repertoire betekenis geven aan deze opzichtige uitgavenpatronen. Ons resultaten illustreren dat opzichtige consumptie een centrale rol speelt in de 283 nummers die wij hebben geanalyseerd. Allereerst zien we dat geld een prominent thema is in de teksten van de rappers; ze gebruiken een veelvoud aan straattaal-synoniemen om over te brengen dat ze 'op geld' zijn. Deze zoektocht naar geld manifesteert zich binnen de rapmuziek op legale wijze, maar de teksten bevatten ook de nodige verwijzingen naar (vroegere) criminele activiteiten. We zien hierbij, in lijn met Veblens 'conspicuous consumption', dat rappers het verdiende geld 'spenden' aan allerhande opzichtige en in het oog springende luxegoederen, zoals designerkleding en sieraden ('drip'), auto's of vakanties, maar ook, anders dan in het werk van Veblen, dat rappers een deel van het door hen verdiende geld 'stacken' door het op zij te zetten. Ook de manier waarop sociale status wordt verkregen middels consumptie is anders van aard dan in de oorspronkelijke analyse van Veblen: in tegenstelling tot emulatie van de consumptiepatronen van de elite om sociale status te verkrijgen, laten onze resultaten zien dat rappers luxegoederen combineren met hele duidelijke elementen uit de straatcultuur - zoals de nabijheid van criminaliteit en specifieke straattaal - en dat hierbij een bepaalde 'ghetto aestethic' (Smith, 2003) behouden blijft.

Zowel het 'spenden' als 'stacken' van de rappers valt, op basis van hun beschrijvingen in hun teksten, te verklaren door ervaringen met armoede, stigmatisering, discriminatie en/of het ontbreken van rolmodellen. We herkennen hierin, net als in eerdere beschouwingen van straatculturen (Nightingale, 1993; Hayward, 2004; Hallsworth, 2013; Ilan, 2015), de centrale uitgangspunten van Youngs (2003, 2007) beschrijving van boulimia van het sociale systeem. Ervaren uitsluiting op diverse deelgebieden van het maatschappelijk leven resulteert hier in mechanismen van opzichtige consumptie (of compensatie) en een focus op harde labeur ('grinden'), zowel in het maken van muziek als met criminaliteit op straat, als innovatieve mertoniaanse (aanpassings)reactie. De nieuwe, succesvolle situatie lijkt hiermee tegelijkertijd verdiend en gerechtvaardigd te worden door de rappers.

Onze analyse van Nederlandstalige rapmuziek toont daarmee dat er onder een ogenschijnlijk oppervlakkige obsessie met geld een duidelijk en uit wetenschappelijk onderzoek bekend narratief schuilgaat van sociaaleconomisch gemarginali- 
seerde groepen in onze samenleving. De inhoud van de rapteksten kan daarbij inzichtelijk maken aan welke thema's Nederlandse jongeren op dagelijkse basis blootgesteld worden en, in navolging van Hunter (2011), welke narratieven de inspiratie vormen voor hun eigen leven en hoe zij de wereld om hen heen proberen te begrijpen. Nederlandse hiphop anno 2020 biedt hiermee de mogelijkheid om, wanneer door de vernislaag van luxegoederen en verspilling van geld aan de oppervlakte heen wordt geprikt, meer inzicht te krijgen in de leefwereld en belevingswereld van jongeren die opgroeien in kwetsbare wijken en omstandigheden in Nederland. De blootstelling aan deze muziek hoeft echter - zoals Van Bohemen et al. (2017) eveneens betogen - niet enkel negatief geïnterpreteerd te worden, maar kan evengoed een positieve rol spelen in het leven van jongeren, bijvoorbeeld omdat zij zich laten inspireren door de (muzikale) mogelijkheden tot opwaartse sociale mobiliteit in Nederland.

Met de popularisering van het rapgenre in Nederland en de daarmee toenemende aandacht voor geld verdienen en uitgeven in de teksten van de rappers rijzen er ook vragen over de authenticiteit van de muziek. Commercialiteit werd in hiphop lange tijd beschouwd als 'selling out' (Wermuth, 2002). Hoewel wij in het onderhavige onderzoek geen systematische analyse hebben verricht naar authenticiteitsclaims, geven onze resultaten wel zicht op enkele veranderingen die de Nederlandse hiphop op dit gebied de afgelopen jaren heeft doorgemaakt. Mede onder invloed van de digitalisering van muziekconsumptie heeft Nederlandse rapmuziek de marge verruilt voor de mainstream, iets dat tot uitdrukking komt in zowel de toegenomen populariteit onder luisteraars als in de plek die het genre inneemt in het bredere muzieklandschap (Duijsings \& Van Niekerk, 2018; El Kaddouri, 2020). Het gevolg hiervan lijkt dat rappers niet langer inhoudelijke of muzikale concessies hoeven te doen om geld te verdienen met hun muziek. Vervolgonderzoek zou nader licht kunnen werpen op de veranderende dimensies van het authenticiteitsvertoog in de hedendaagse hiphop.

Een aanverwant onderwerp betreft de overduidelijke invloed van Amerikaanse rapmuziek op de door ons bestudeerde teksten. De overvloed aan Amerikaanse leenwoorden in Nederlandstalige rap geeft zicht op de culturele reproductie van een mondiale rapcultuur. Tegelijkertijd is de manifestatie van opzichtige consumptie in Nederlandse rap, zowel in de verwijzingen naar de dure automerken, merkkleding en sieraden als de genoemde geldbedragen, voor een groot deel ook te typeren als 'Nederlands'. Amerikaanse rapmuziek lijkt hierbij meer te fungeren als interpretatief kader om hun eigen leven te begrijpen en in raps te vangen dan als (stereotypische) blauwdrukken die klakkeloos worden gereproduceerd in Nederlandse vertalingen. Voor een deel kan het 'Nederlandse karakter' van uitgaven verklaard worden doordat de Nederlandse rappers een aanzienlijk kleinere afzetmarkt hebben dan de Engelstalige miljardairs en miljonairs.

In deze bijdrage hebben we ons gericht op het beschrijven en duiden van een muzikale 'cultuur van exces' in populaire Nederlandse rapmuziek. Het dominante discours rondom opzichtige consumptie dat in door ons bestudeerde teksten doorklinkt, betekent echter niet dat Nederlandstalige hiphop hiertoe gereduceerd kan en zou moeten worden. Ook andere maatschappelijk relevante thema's, waaronder ongelijkheid, uitsluiting, criminaliteit, geweld, gender en identiteit, vallen 
immers te herkennen in de door ons bestudeerde teksten. Deze onderwerpen lenen zich bij uitstek voor nader onderzoek naar Nederlandse rapmuziek. Toekomstige studies zouden zich naast de teksten eveneens kunnen richten op de bijbehorende visuele producten van de rappers op YouTube en andere sociale media. Voor een meer holistisch beeld van de betekenis en interpretatie van de teksten en video's zou vervolgonderzoek zich, tot slot, ook moeten richten op de producenten en consumenten van rapmuziek van Nederlandse bodem.

\section{Literatuur}

Bahara, H. (2019, 23 oktober), Is drillmuziek de katalysator voor de recente geweldsgolf onder jongeren? NRC Handelsblad. Gevonden via: www.volkskrant.nl/nieuwsachtergrond/is-drillmuziek-de-katalysator-voor-de-recente-geweldsgolf-onderjongeren b778afd9, laatst geraadpleegd op 20 januari 2020.

Bakker, S.R. \& V. van de Wetering (2015), Bedreigende rap en de kunstexceptie. Proces, tijdschrift voor strafrechtspleging, 94(3), 175-187.

Berkelder, N. (2019, 1 oktober), Het dreigen met messen is een hype onder jongeren: eerst online en nu ook in de echte wereld. Algemeen Dagblad. Gevonden via: www.ad.nl/ rotterdam/het-dreigen-met-messen-is-een-hype-onder-jongeren-eerst-online-en-nuook-in-de-echte-wereld add77a57, laatst geraadpleegd op 20 januari 2020.

Bohemen, S. van, L. den Hertog \& L. van Zoonen (2017), Music as a resource for the sexual self: An exploration of how young people in the Netherlands use music for good sex. Poetics, 66, 19-29.

Brown, E. (2008), Fat Cat, 50 Cent, and the Rise of the Hip-hop Hustler: Queens Reigns Supreme. New York, NY: Anchor Books.

Buiks, P.E.J. (1983), Surinaamse jongeren op de Kruiskade. Overleven in een etnische randgroep. Deventer: Van Loghum Slaterus B.V.

Campbell, C. (1995), Conspicuous confusion? A critique of Veblen's theory of conspicuous consumption. Sociological Theory, 13(1), 37-47.

Currid-Halkett, E., H. Lee \& G.D. Painter (2019), Veblen goods and urban distinction: The economic geography of conspicuous consumption. Journal of Regional Science, 59(1), 83-117.

Densley, J.A. (2013), How Gangs Work. New York: Palgrave Macmillan.

Duijsings, I. \& R. van Niekerk (2018), De cijfers van Nederlandse hiphop zijn extreem, echt extreem. NOS. Gevonden via https://nos.nl/op3/artikel/2265576-de-cijfers-vannederlandse-hiphop-zijn-extreem-echt-extreem.html .

El Hadioui, I. (2011), Hoe de straat de school binnendringt: denken vanuit de pedagogische driehoek van de thuiscultuur, de schoolcultuur en de straatcultuur. Amsterdam: Uitgeverij van Gennep B.V.

El Kaddouri, W. (2020, 13 mei), Jongens van de Straat. De Groene. Gevonden via: www.groene.nl/artikel/jongens-van-de-straat, laatst geraadpleegd op 27 mei 2020.

Evers, J. (2015), Kwalitatieve analyse: kunst én kunde. Amsterdam: Boom Lemma uitgevers.

Hallsworth, S. (2013), The gang and beyond: Interpreting violent street worlds. Basingstoke: Palgrave Macmillan.

Hayward, K. (2004), City Limits: Crime. Consumer Culture and the Urban Experience. London: Glasshouse.

Hunter, M. (2011), Shake it, baby, shake it: consumption and the new gender relation in hip-hop. Sociological perspectives, 54(1), 15-36. 
Ilan, J. (2015), Understanding Street Culture. Poverty, crime, youth and cool. London: Palgrave MacMillan.

Ilan, J. (2020), Digital Street Culture Decoded: Why Criminalizing Drill Music is Street Illiterate and Counterproductive. The British Journal of Criminology, doi:10.1093/bjc/ azz086.

Jong, J.D. de (2007), Kapot Moeilijk. Een etnografisch onderzoek naar opvallend delinquent groepsgedrag van 'Marokkaanse' jongens. Amsterdam: Aksant.

Kubrin, C.E. (2005), Gangstas, thugs, and hustlas: Identity and the code of the street in rap music. Social problems, 52(3), 360-378.

Kubrin, C.E. (2006), 'I see death around the corner': Nihilism in rap music. Sociological Perspectives, 48(4), 433-459.

McIntyre, R. (1992), Consumption in contemporary capitalism: Beyond Marx and Veblen. Review of Social Economy, 50(1), 40-60.

Miller-Young, M. (2008), Hip-hop honeys and da hustlaz: Black sexualities in the new hiphop pornography. Meridians: feminism, race, transnationalism, 8(1), 261-292.

Mullainathan, S. \& E. Shaffir (2014), Scarcity: The true cost of not having enough. London: Penguin Books Ltd.

Nightingale, C.H. (1993), On the Edge: A History of Poor Black Children and Their American Dreams. New York: Basic Books.

Pattillo-McCoy, M. (1999), Black Picket Fences: Privilege and Peril Among the Black Middle Class. Chicago: The Chicago of University Press.

Podoshen, J.S., S.A. Andrzejewski \& J.M. Hunt (2014), Materialism, conspicuous consumption, and American hip-hop subculture. Journal of International Consumer Marketing, 26(4), 271-283.

Raatgever, S. (2019, 24 maart), Artiesten zetten schaar in muziek door Spotify. Het Parool. Gevonden via: www.parool.nl/amsterdam/artiesten-zetten-schaar-in-muziek-doorspotify bb970a00, laatst geraadpleegd op 20 januari 2020.

Rehn, A. \& D. Sköld (2005), 'I love the dough': Rap lyrics as minor economic literature. Culture and Organization, 11(1), 17-31.

Roest, F.A. de (2017), Buurtvaders. Een kritische lezing van represent als performance door vier Nederlandse hiphopartiesten. Utrecht: Universiteit Utrecht (ongepubliceerde masterscriptie).

Roks, R.A. (2013), De straat praat? De performance van 'street credibility'. Tijdschrift over Cultuur \& Criminaliteit, 3(3), 14-31.

Roks, R.A. (2020), Keeping it (hyper)real: a musical history of rap's quest beyond authenticity. In: F. Bovenkerk \& D. Siegel (eds.), Music and Crime. Cham, Switzerland: Springer.

Sansone, L. (1992), Schitteren in de schaduw. Overlevingsstrategieën, subcultuur en etniciteit van Creoolse jongeren uit de lagere klasse in 1981-1990. Amsterdam: Het Spinhuis.

SMIB (2017), Smibanese Woordenboek. Amsterdam: Smibanese University.

Storrod, M.L. \& J.A. Densley (2017), 'Going viral' and 'going country': the expressive and instrumental activities of street gangs on social media. Journal of Youth Studies, 20(6), 677-696.

Tilman, R. (2006), Colin Campbell on Thorstein Veblen on conspicuous consumption. Journal of Economic Issues, 40(1), 97-112.

Trigg, A.B. (2001), Veblen, Bourdieu, and conspicuous consumption. Journal of Economic Issues, 35(1), 99-115.

Veblen, T. (2017), The theory of the leisure class. New York: Routledge.

Vughts, P. (2020, 25 april), Amsterdamse politie wil criminele rappers hun podium afnemen. Het Parool. Gevonden via: www.parool.nl/amsterdam/amsterdamse-politie-wil- 
criminele-rappers-hun-podium-afnemen befb80c4, laatst geraadpleegd op 27 mei 2020.

Wermuth, M. (2002), No sell out: de popularisering van een subcultuur. Amsterdam: Aksant.

Young, J. (2003), Merton with energy, Katz with structure: The sociology of vindictiveness and the criminology of transgression. Theoretical Criminology, 7(3), 389-414.

Young, J. (2007), The Vertigo of Late Modernity. London: Sage. 